\title{
Female fertility in Pinus sylvestris L var. compacta (TOSUN) clonal seed orchard
}

\author{
Murat ALAN \\ Karabuk University, Faculty of Forestry, Karabuk, TURKEY \\ muratalan@karabuk.edu.tr
}

Received Date: 31.01 .2017

Accepted Date: 30.09 .2017

\section{Abstract}

Aim of study: The intention of current study is to compile information on female fertility variation and estimate some parameters related to fertility in the seed orchard for 2015.

Area of study: The seed orchard was established in April 2004 in Eflani of Karabuk, Turkey.

Material and Methods: The seed orchard included 823 ramets of 26 clones at $5 \mathrm{~m}$ x 5m. Five ramets per clone were chosen randomly and female strobili in 130 ramets were counted in June 2015. All of the female strobili over the entire crown were counted on all chosen ramets. Female fertility variation, status number and relative status number were estimated.

Main results: Average numbers of female strobili per clone were ranged from 4.2 to 75.0 . The most fertile clone was \#351, the less fertile one was \#354. The top 30\% of clones produced $50.6 \%$ of total female strobili. Most of female strobili were appeared single but the rest of them were formed clusters. Number of strobilus of clusters was ranged from 2 to15. In analyses of variance, differences in clonal female strobilus production were not statistically significant $(\mathrm{P}=0.07)$. Female fertility variation $\left(\psi_{f}\right)$, effective status number $\left(N_{s}\right)$ and relative status number $\left(N_{r}\right)$ were $2.14,12.15$ and 0.48 , respectively indicating low genetic diversity

Research highlights: Compiled first information on female fertility in the frame of this research can be used for management of the seed orchard on conservation and landscape.

Keywords: Seed orchard, female fertility variation, status number, relative status number, Scots pine

\section{Pinus sylvestris L var. compacta (TOSUN) aşılı tohum bahçesinde}

\section{dişi çiçek üretkenliği}

\section{Özet}

Çalışmanin amact: Yapılan çalışma, tohum bahçesinde 2015 y1lı için, dişi çiçek üretlenliğinin değişimi ve üretkenlikle ilgili bazı parametrelerin tahmin edilmesini hedeflemektedir.

Çalışma alanı:Tohum bahçesi 2004 yılında Türkiye'nin Karabük İli, Eflani İlçesinde kurulmuştur.

Materyal ve Yöntem:Tohum bahçesi $5 \times 5$ aralı mesafe ile 26 klona ait 826 ramet içermektedir. Her bir klona ait rastgele seçilmiş ve 130 ramette Haziran 2015 'te dişi çiçeklerin tamamı sayılmıştır. Dişi çiçek üretkenliğinin değişimi, akrabasızlık sayısı ve oransal akrabasızlık sayısı tahmin edilmiştir.

Sonuçlar:Klon başına ortalama dişi çiçek sayısı 4.2 ile 75.0 arasında değişmiştir. En yüksek üretken klon \#351, en düşük üretken klon \#354 olmuştur. En çok üretken \%30 klon toplam dişi çiçeklerin \%50.6'sını üretmişlerdir. Çoğu dişi çiçekler tekli olmuş, ancak diğerleri kümeli bir yapı oluşturmuşlardır. Kümelerin sayısı 2 ile 15 arasında değişmiştir. Varyans analizinde klonal çiçek üretimindeki farklılıklar istatistik olarak anlamlı bulunmamıştır $(\mathrm{P}=0.07)$. Dişi çiçek üretkenliğinin değişimi $\left(\psi_{f}\right)$, akrabasızlık sayısı $\left(N_{s}\right)$ ve oransal akrabasızlık sayısı $\left(N_{r}\right)$ sirasıyla $2.14,12.15$ ve 0.48 bulunmuş, düşük genetik çeşitlilik ortaya çıkmıştır.

Araştırma vurguları: $\mathrm{Bu}$ araştırma kapsamında, dişi çiçek üretkenliği konusunda elde edilen ilk bilgiler, tohum bahçesimim koruma ve peyzaj amaçlı yönetimi için kullanılabilecektir.

Anahtar kelimeler: Tohum bahçesi, dişi çiçek üretkenliği, akrabasızlık sayısı, oransal akrabasızlık sayısı, Sarıçam 


\section{Introduction}

Breeding activities were started in 1964, but first National Tree Breeding Program (NTBP) of Turkey was implemented at 1994 (Koski and Antola, 2003). Pinus sylvestris was one of the target species in NTBP. In this context, 21 seed orchards occupying 116.4 ha in Pinus sylvestris have been established so far (URL1, 2016). Two out of 21 seed orchards were established for ex situ conservation in Pinus sylvestris $\mathrm{L}$ var. compacta (TOSUN). These orchards were clonal seed orchards, established by using grafted clones. One of them was researched on fertility variation.

Seed orchards are the connection between breeding programs and plantation establishment. They are composed and managed to produce seeds of high-grade genetic and physiologic quality (Kang and Lindgren, 1999).

Flowering processes in an orchard are of great importance, since they affect gene exchange among clones and genetic configuration of seeds obtained from seed orchard. So genetic composition of orchards seeds is determined mainly the numbers of female and male strobili produced by each clone (Kang, 2000; Kang and Mullin, 2007; Prescher et al., 2007).

Some researches on flowering system were carried out for Pinus sylvestris (Bilir et al., 2006; Dutkuner et al., 2008; Bilir et al., 2012). There is no research on flowering system for Pinus sylvestris L var. compacta (TOSUN) seed orchard. Grafts of the seed orchard are in special form and distribution of parent trees (plus trees) is scattered and limited area of Bolu province of Turkey. So the seed orchard was established for ex situ conservation.

Research on mating system was started in the Pinus sylvestris L var. compacta (TOSUN) seed orchard in 2015 and will be completed until 2017. The intention of current study is to compile information on female fertility variation and estimate some parameters related to fertility in the seed orchard for 2015.

\section{Material and Methods}

Data were collected a Pinus sylvestris L var. compacta (TOSUN) seed orchard. The seed orchard was established in April 2004 including 823 ramets of 26 clones at $5 \mathrm{~m} \mathrm{x}$ $5 \mathrm{~m}$ spacing in Eflani of Karabuk, Turkey (latitude $41^{\circ} 23^{\prime} 45^{\prime \prime} \mathrm{N}$, longitude $32^{\circ} 49^{\prime}$ $07 " \mathrm{E}$ and altitude $890 \mathrm{~m}$ ). Number of ramets per clone varied from 3 to 37 . The seed orchard can be considered as a young seed orchard. Usually, Pinus sylvestris seed orchard initiates cone production at age ten in Turkey (Koski and Antola, 1993). The seed orchard was at 11 ages when data were collected in 2015.

Five ramets per clone were chosen randomly and female strobili in 130 ramets were counted in June 2015. All of the female strobili over the entire crown were counted on all chosen ramets. Logarithmic transformation was applied prior to analyses of variance for flower numbers. Height and crown diameter were measured and calculated volume index of sphere or cone shape of grafts. Volume index of each graft was used as covariate in the statistical model. Following statistical model used was:

$y_{i j}=\mu+A X_{i j}+c_{i}+e_{i j}$

Where $y_{i j}$ observation on the $\mathrm{j}^{\text {th }}$ ramet $\mathrm{i}^{\text {th }}$ clone, $\mu$ is overall mean, $A$ regression coefficient, $X_{i j}$ volume index of grafts $(i j=1, . .130), \quad c_{i}$ random effect $i^{\text {th }}$ clone $(\mathrm{i}=1, \ldots 26), e_{i j}$ experimental error.

Female fertility variation $\left(\psi_{f}\right)$ can be described by coefficient of variation $(C V)$ in strobilus production, a measure suggested by Kang and Lindgren (1999); Kang and Mullin (2007) as:

$\psi_{f}=C V_{f}^{2}+1$

Where; $C V_{f}$ is the coefficient of variation in female strobilus production among clones.

Effective number was calculated by the concepts of status number (Lindgren and Mullin, 1998) and effective parent number (Kang and Lindgren, 1999). Status number calculations were based on the fertility variation at female level (Kang and Lindgren, 1999; Kang and Mullin, 2007) as: 
$N_{s(f)}=N / \psi_{f}$

Where $N_{s(f)}$ is status effective number of female.

Relative status number $\left(N_{r}\right)$ was calculated as the ratio of status number $\left(N_{s}\right)$ over census number $(N)$ (Kang and Mullin, 2007).

\section{Results}

Average, minimum, maximum female strobilus production, coefficient of variation and standard deviation are presented in Table 1. Average female strobilus was 36.3 per clone. Coefficient of variation and standard deviation were 1.06 and 38.7, respectively. Female strobilus was ranged from 4.2 to 75.0 per in

2015.

Table 1. Average, minimum, maximum female strobilus per clone, coefficient of variation $(\mathrm{CV})$, standard deviation (Sd) in 2015

\begin{tabular}{lllll}
\hline Average & Minimum & Maximum & $C V$ & Sd \\
\hline $36.3 \pm 3.6$ & 4.2 & 75.0 & 1.06 & 38.7 \\
\hline
\end{tabular}

The analysis of variance of clones was not revealed statistically significant differences among clones on both female strobilus production and volume index

Table 2. The analyses of variance on female fertility

\begin{tabular}{lcccc}
\hline Source of variation & Degree of freedom & Mean square & F Value & $\operatorname{Pr}>$ F \\
\hline Volume index & 1 & 2.340 & 2.5 & 0.12 \\
\hline Clones & 25 & 1.473 & 1.6 & 0.08 \\
\hline Error & 57 & 0.936 & & \\
\hline
\end{tabular}

Female fertility variation $\left(\psi_{f}\right)$, effective status number $\left(N_{s}\right)$ and relative status number $\left(N_{r}\right)$ were $2.14,12.15$ and 0.48 , respectively. The most fertile clone was
\#351, the less fertile one was \#354. The top $30 \%$ of clones produced $50.6 \%$ of total female strobili, and the lowest $19 \%$ of clones produced \%5.4 of total female strobili (Figure 1).

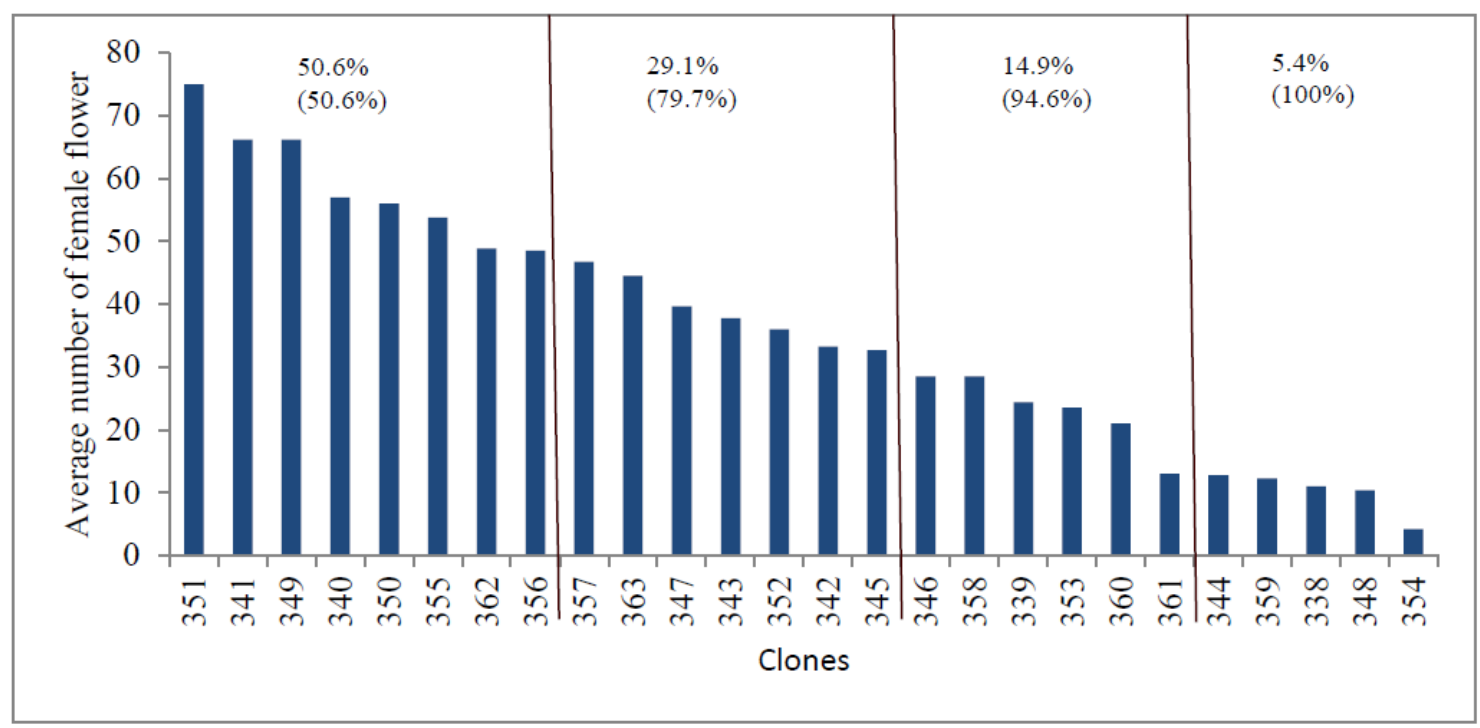

Figure 1. The contribution of clones in female strobili production 
Female flowers were appeared mostly single but the rest of them were formed clusters. Flower number in clusters was ranged from 2 to15 (Figure 2). Average of the highest cluster including 15 flowers was 13.4 and in the sixth place. Average of the least cluster including 9 flowers was 2.2.

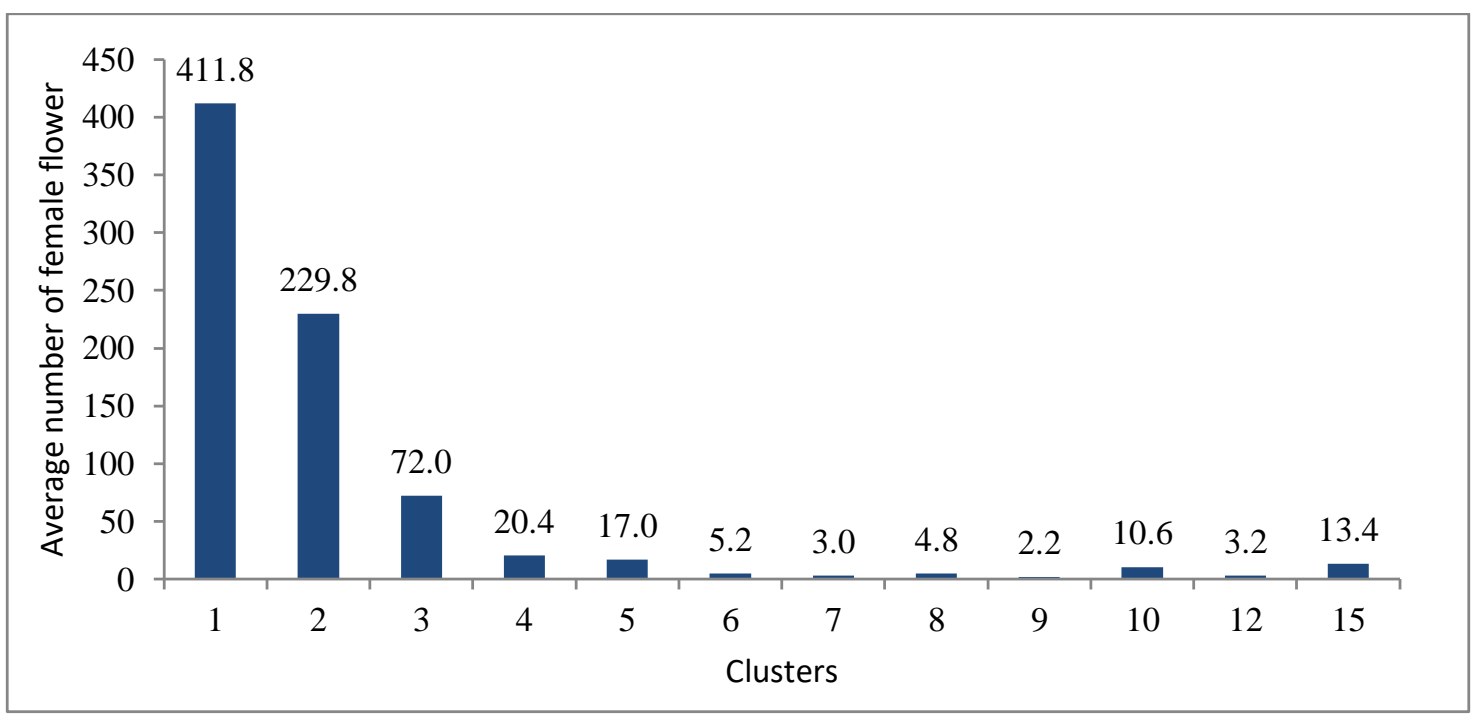

Figure 2. Average number of single flower and clusters

\section{Discussion and Conclusion}

The production of female strobili was found to vary among clones in the clonal seed orchard. Average female strobili production was 36.3 per clone. Bilir and Temirağa (2012) found that average female strobili productions were 150.4 and 179.8 for two mature Pinus sylvestris seed orchards. On the other hand the highest production clone \#351 was 75, the lowest production clone \#354 was 4.2 indicating unequal female contribution at clonal level in the seed orchard.

The analysis of variance of clones was not revealed statistically significant differences among clones on both female production and volume index. The data were unbalanced and some grafts of clones were not produced female flower, some grafts of clones were produced 143 female flowers. Therefore, clonal differences might not be statistically significant. Volume index also did not affect flower production as a covariate, in other words, female production was not related crown size of grafts.

Sibling coefficient showing fertility variation was 2.14 in this research. If sibling coefficient is 1 , then coefficient of variation is zero and each clone contributes equal strobili in seed orchard (Prescher et al., 2007). Bilir and Temirağa (2012) found that sibling coefficients of female strobili were between 1.03 and 1.07 in two mature Pinus sylvestris seed orchard. Sibling coefficient in this research is higher than sibling coefficient of the mature seed orchards. This situation might be sourced that seed orchard in this research was young and its grafts were special formed. In this context, Prescher et al. (2007) claimed that variation in fertility seemed to be higher in young seed orchards and in years when seed production as low.

Status number and relative status number were 12.15 and 0.48 , respectively in this research. The status number explains how many ideal orchard clones would give rise to the considered crop. It gives a measure for comparing different seed orchard designs, seed orchard management actions, consequences of pollen contamination, etc., for the expected relatedness and gene diversity in a seed orchard crop. (Lindgren and Mullin, 1998). To compare with other studies, using of relative status number is better than using status number. Bilir and Temirağa (2012) found that female relative status numbers were 0.94 and 0.97 for one year in two mature Pinus sylvestris seed 
orchards. Kang and Mullin (2007) estimated female relative status numbers between 0.500.93 for five years and 0.94 for pooled data in a mature Chamaecyparis obtusa seed orchard. In the light of these explanations, our status number and relative status number were low: half of census number. So, genetic diversity was also low in the seed orchard. Female production contributions of clonal level were ranged. The top $30 \%$ of clones ( 8 clones) and the lowest $19 \%$ of clones (5 clones) produced $50.6 \%$ and $\% 5.4$ of total female strobili, respectively in this research. In the Pinus koreansis S. et Z., the top 25\% of clones and the lowest \%25 of clones produced $52.3 \%$ and $6.0 \%$ of total female strobili, respectively for five years (Kang and Lindgren, 1999). In the other hand, Burzcyk and Chalupka (1987) found that the top 25\% of clone and the lowest $25 \%$ of clones produced $\% 35.44$ and 13.84 of total cone. In the light of these explanations, clonal contributions on production were usually unequal in the seed orchards.

In the Pinus sylvestris $\mathrm{L}$ var. compacta (TOSUN) seed orchard, cluster cones were more common than Pinus sylvestris seed orchards. A cluster including maximum flower numbers was 15 . Other clusters including between 2-12 flowers were determined. Cluster strobili might be special structure for Pinus sylvestris L var. compacta (TOSUN).

The Pinus sylvestris L var. compacta (TOSUN) seed orchard was established for ex situ conservation. In the other hand, the seed orchard can be serviced for landscape, because Tosun (2012) was categorized three different crown shape: spheroidal, half spheroidal and umbrella. Compiled first information on female fertility in the frame of this research can be used for management of the seed orchard on conservation and landscape.

\section{References}

Bilir, N., Prescher, F., Ayan, S., Lindgren, D. (2006). Growth characters and number of strobili in clonal seed orchards of Pinus sylvestris. Euphytica, 152(2), 293-301.

Bilir, N., Temirağa, H. (2012). Fertility variation and status number in clonal seed orchards of Pinus sylvestris. Pak. J. Biol. Sci., 15(22), 1075-1079.

Burczyk, J., Chalupka, W. (1997). Flowering and cone production variation and its effect on parental balance in a Scots pine clonal seed orchard. Annals of Forest Science, 54, 129-144.

Dutkuner, I., Bilir, N., Ulusan, M. D. (2008). Influence of growth on reproductive traits and its effect on fertility and gene diversity in a clonal seed orchard of Scots pine. Journal of Environmental Biology, 29, 349-352.

Kang, K. S. (2000). Clonal and annual variation of flower production and composition gamet gene pool in a clonal seed orchard of Pinus densiliflora. Can. J. For. Res., 30, 1275-1280.

Kang, K. S., Lindgren, D. (1999). Fertility variation among clones of Korean pine (Pinus koreansis S. et Z.) and its implications on seed orchard management. Forest Genetics, 6, 191-200.

Kang, K. S., Mullin, T. J. (2007). Variation in clone fertility and its effect on the gene diversity of seeds from a seed orchard of Chamaecyparis obtusa in Korea. Silvae Genetica, 56, (3-4), 134-137.

Koski, V., Antola, J. (1993). Turkish National Tree Breeding and Seed Production Program for Turkey (19942003). Cooperated with ENSO Forest Development Inc. and Forest Tree Seeds and Tree Breeding Institute.

Lindgren, D., Mullin, J. (1998). Relatedness and status number in seed orchard crops. Can. J. For. Res., 28, 276-283.

Prescher, F., Lindgren, D., Almqvist, C., Kroon, J., Lestander, T., Mullin, T. (2007). Female fertility variation in mature Pinus sylvestris clonal seed orchards. Scandinavian Journal of Forest Research, 22 (4), 280-289.

Tosun, S. (2012). Ebe pines. ISBN:978-605$86469-0-2, \quad 58$ s, Türkiye Tabiatını Koruma Deneği, Bolu Şubesi Yayını (in Turkish and English).

URL1. (2016). Web page of Orman Ağaçları ve Tohumları Islah Araştırma Enstitüsü Müdürlüğü (http://ortohum.ogm.gov.tr/SitePages/OG M/OGMDefault.aspx) 